\title{
Az Airbnb szerepe a Balatoni Turisztikai Régióban
}

\author{
Szerzők: Dudás Gábor ${ }^{1}$ - Nagy Gyula² - Boros Lajos ${ }^{3}$
}

Naponta emberek tízezrei döntenek úgy, hogy nem a hagyományos, hanem a peer-to-peer (P2P) elven múködő online szállásmegosztó platformokon - ilyen például az Airbnb - ismeretlenek által meghirdetett szálláshelyeken szállnak meg. Ez a folyamat napjainkban még döntôen nagyvárosi jelenség, azonban egyre inkább teret nyer a jelentôs turisztikai potenciállal rendelkezó térségekben, komoly kihívások és verseny elé állítva a hagyományos piaci szereplőket. A tanulmány célja, hogy a korábbi, elsôsorban nagyvárosokra fókuszáló Airbnb kutatásokkal szemben egy turisztikai régióban (Balaton Kiemelt Üdülókörzet) vizsgálja meg az Airbnb kinálatát és területi jellemzôit. A kutatás eredményei azt mutatják, hogy a balatoni Airbnb kinálat illeszkedik a hazai és nemzetközi trendekhez, azonban a szálláskinálat volumene jelentôsen elmarad a fövárosétól. A vizsgálat rávilágított továbbá arra, hogy az Airbnb-n keresztül történó professzionális lakáskiadás fokozottan van jelen a térségben, így a balatoni régióban az Airbnb nem tekinthetô pusztán a felesleges ingatlankapacitások magánjellegú megosztására és hasznosítására használt platformnak (ahogyan maga a vállalat értelmezi saját szerepét a nyilvánosság felé), hanem bizonyos esetekben sokkal inkább egy üzleti motiváció által vezérelt lakáskiadó oldal.

Kulcsszavak: Balaton, Airbnb, magánszállásadás, sharing economy, P2P szállásadás.

\section{Bevezetés}

Az elmúlt években a turizmus iparága globális szinten folyamatos növekedést mutat (FORNOGARIBALDI 2015), melyhez nagyban hozzájárul a több szerzô értelmezésében is (lásd például CHENG 2016, GUTTENTAG 2015, SALVIONI 2016, SCHNEIDER 2017, SAHLMAN 2018) „bomlasztó innovációként" számon tartott közösségi gazdaság (sharing economy) egyre terjedő jelensége, amely jelentősen megváltoztatta a globális turizmus szabályait. A sharing economy egy olyan gazdasági-technológia jelenség (HAMARI et al. 2015), amely az infokommunikációs technológiák fejlődésén és széleskörú elterjedésén alapul. E tanulmánynak nem célja a közösségi gazdaság fogalmának részletes áttekintése, így ehelyütt azt hangsúlyoznánk, hogy álláspontunk szerint az online platformok használata, a kihasználatlan kapacitások megosztása, a kapcsolat és használat átmeneti jellege, illetve a fogyasztók közötti közvetlen kapcsolat a közösségi gazdaság

\footnotetext{
tudományos munkatárs, MTA Közgazdaság- és Regionális Tudományi Kutatóközpont Regionális Kutatások Intézete Alföldi Tudományos Osztály, dudasgabor5@gmail.com

${ }^{2}$ egyetemi tanársegéd, Szegedi Tudományegyetem, geo.nagy.gyula@ gmail.com

${ }^{3}$ egyetemi docens, Szegedi Tudományegyetem, borosl@geo.u-szeged.hu
}

meghatározó elemei (DUDÁS-BOROS 2019). Kihasználva az internet, a web 2.0, a peer-to-peer (P2P) platformok, valamint a mobilkommunikáció nyújtotta lehetőségeket, a közösségi gazdaság égisze alá sorolt vállalatok (azaz a szereplőket öszszekötô internetes platformok) a turizmus területén - annak számszerú növekedésén túl - nagyban hozzájárulnak új utazási formák, szokások és eszközök elterjedéséhez, és megjelenéséhez (FORNO-GARIBALDI２015， SÜLI-MARTYINCSAMANGÓ 2017).

A turizmus területéhez számos sharing economy vállalatot kapcsolhatunk a közösségi szállásmegosztó oldalaktól (például Airbnb, Homeaway) a P2P közlekedési platformokon át (például Uber, BlaBlaCar, Oszkár) egészen a gasztro platformokig (például EatWith, VizEat). Ezek közül a legjelentősebbnek tartott sharing economy vállalat a rövidtávú szállásszolgáltatást kínáló P2P szállásmegosztó platform, az Airbnb (BÁLINT-TRÓCSÁNYI 2016, GUTIÉRREZ et al. 2017), amelyen keresztül hétköznapi emberek adhatják bérbe turisták számára a kihasználatlanul álló ingatlanjaikat, tereiket szállásként. 2008-as megalapítása óta az Airbnb dinamikus növekedést mutat, napjainkra a szolgáltatás a világ több mint 81000 városában és 191 országában van jelen, továbbá az oldalon kínált szállások száma meghaladja az ötmilliót (AIRBNB 2018), amivel jelentôsen felülmúlja a nagy szállodaláncok kínálatát. Mindemellett az Airbnb piaci helyzetét és erejét is jól mutatja, hogy a vállalat értékét 
több mint 38 milliárd dollárra értékelik (FORBES 2018), amivel olyan hotelláncokat múl felül, mint a Hilton Hotels \& Resorts, a Marriott, vagy a Hyatt (STATISTA 2018).

A P2P szállásadás - elsősorban az Airbnb megerősödésével jelentős piaci részesedésre tett szert a "hagyományos" szállásadással (főként a szállodákkal, panziókkal) szemben. Ezzel összhangban a kutatók is fokozottan érdeklődnek az Airbnb és annak turizmusra - elsősorban a szállodaiparra - gyakorolt hatásai iránt. A témában született tanulmányok jelentős része az Airbnb hotelárakra (ZERVAS et al. 2017), valamint a hotelek teljesítményére (BLAL et al. 2018) gyakorolt hatását elemzi. GININDZA és TICHAAWA (2017) azt vizsgálta továbbá, hogy a közösségi szállásmegosztó platform megjelenésével hogyan alakultak a hotelek szobakihasználtságának adatai, míg FANG és szerzőtársai (2016) az Airbnb-nek a turizmus területén történő foglalkoztatásra gyakorolt hatására fókuszáltak. Mindemellett születtek tanulmányok, amelyek az Airbnb és a hotelszektor kínálatának térbeliségét hasonlították össze (GUTIÉRREZ et al. 2017, GYÓDI 2017), továbbá vizsgálták a turisták motivációját is (GUTTENTAG et al. 2018), hogy feltérképezzék, melyek azok a tényezők, amelyek abban befolyásolják őket, hogy az Airbnb-t vagy a hagyományos szállásadókat válasszák. A nemzetközi kutatások mellett számos hazai vizsgálat is született az Airbnb hatásait elemezve, amelyek elsősorban a fóvárosi Airbnb szállások térbeli elhelyezkedését (BOROS et al. 2018, DUDÁS et al. 2017a, KARAKASNÉ MORVAY 2017), a közösségi szállásadás megjelenésével a budapesti szállásadópiacon végbement változásokat (JANCSIK et al. 2018), valamint az Airbnb múködését és szabályozását befolyásoló szabályozási kereteket érintik (JANCSIK et al. 2018, RANCHORDÁS et al. 2016, SMITH et al. 2018). Mind nemzetközi, mind hazai viszonylatban azonban a P2P szállásadáshoz kapcsolódó folyamatok vizsgálatának középpontjában döntően fóvárosok, nagyvárosok állnak (DUDÁS et al. 2017b, GUTIÉRREZ et al. 2017), hisz a legtöbb Airbnb ott található. Bár az utóbbi időben születtek tanulmányok a településhierarchia alacsonyabb szintjeire is (BÁLINT-MAGYAR-PAPP 2016, DUDÁS et al. 2018), ezek száma elenyészô. Az előzőekkel összhangban tehát a tanulmányunk célja, hogy a korábbi kutatásokkal ellentétben ne egy nagyvárosban vizsgálja a P2P szállásadás helyzetét, elterjedését, hanem egy jelentős turisztikai potenciállal rendelkező térségben, a Balaton Kiemelt Üdülőkörzet ${ }^{4}$ (BKÜ) településein. A BKÜ

\footnotetext{
${ }^{4}$ A tanulmány további részében a Balaton Kiemelt Üdülőkörzet, a balaton térség és a balatoni régió kifejezéseket egymás szinonimáiként használjuk.
}

kiválasztását a hasonló térségi szintre vonatkozó vizsgálatok alacsony száma indokolja, így kutatásunkkal hozzájárulhatunk annak bemutatásához, hogy egy turisztikai régióban milyen mértékben és hogyan terjedt el a P2P szállásadás jelensége.

A tanulmány elsó felében ismertetjük a kutatás során alkalmazott módszereket, majd áttekintjük a balatoni szállásadás keresleti és kínálati oldalának alakulását. A tanulmány második felében bemutatjuk az Airbnb helyzetét a BKÜ településein, végül a tanulmányt az összegzés és a kutatás további irányai zárják. A tanulmány célja és terjedelmi korlátai nem teszik lehetővé a közösségi gazdaság, illetve a P2P szállásadás fogalmainak részletesebb bemutatását. E kérdésekkel számos hazai és nemzetközi publikáció foglalkozik. A közösségi gazdasággal kapcsolatban DUDÁS és BOROS (2019), míg a P2P szállásadással kapcsolatban JANCSIK és szerzőtársainak (2018) tanulmánya nyújt részletes áttekintést.

\section{Alkalmazott módszerek}

Vizsgálatunkat az elemzési mintaterület lehatárolásával kezdtük, amelyet a $\mathrm{BKÜ}^{5}$, valamint a vele megegyező Balaton idegenforgalmi régiót alkotó 180 településsel azonosítottuk (DOMONKOS et al. 2016). Ezt követően az adatgyứjtést és az elemzést kvantitatív módszertani bázisra alapoztuk, és korszerú, internetes adatgyújitésen alapuló technikákat (PÁSZTOR et al. 2017) is alkalmaztunk.

A P2P szállásadás - mint az Airbnb - vizsgálata számos kihívás elé állítja a kutatókat, ugyanis a hivatalos statisztikai adatbázisokban csak meglehetôsen korlátozottan állnak rendelkezésre adatok a megosztáson alapuló szállásadásról, melyek a szektorban tapasztalható szürke- és feketegazdaság (be nem jelentett szállásadás) kiterjedtsége miatt még hiányosak is (DUDÁS et al. 2016, 2018). Magyarországon az Airbnb-n keresztül történő szálláskiadást a $\mathrm{KSH}$ az egyéb nem üzleti célú szállások (továbbiakban: magánszállások) közé sorolja, azonban a magánszállásadókra vonatkozó hazai statisztikai adatállomány meglehetôsen korlátozott (JANCSIK et al. 2018), így a szükséges Airbnb adatok lekérdezése érdekében web scraping technológián alapuló adatgyuujtést végeztünk. Ezt a technológiát, módszert napjainkban egyre szélesebb körben alkalmazzák a P2P szállásadás vizsgálatához. Így például JANCSIK és szerzôtársai (2018) a budapesti Airbnb piac alakulásának vizsgálatát alapozták ilyen típusú adatgyújtésre,

${ }^{5}$ A települések listáját a Magyarország és egyes kiemelt térségeinek területrendezési tervéről szóló 2017. évi T/18783 számú törvényjavaslat tartalmazza (http://www.parlament.hu/irom40/18783/HTMLT18783. pdf). 
Lektorált tanulmányok

GUTIÉRREZ és szerzőtársai (2017) a barcelonai Airbnb piacot hasonlították össze a hagyományos szállásadó szektorral, míg TEUBNER és szerzótársai (2017) az egyes szállásadók hírnevének hatását vizsgálták az Airbnb szállások áraira vonatkozóan. A web scraping technológia lényege, hogy egy számítógépes program, előre betáplált paraméterek alapján, felkeresi az adott weboldalt, és az azon található információkat egy adatbázisba menti (OLMEDILLA et al. 2016). A balatoni térségre vonatkozó Airbnb adatok 2018 júliusára vonatkoznak. A vizsgálat időpontjában az adatbázisunkba összesen 2417 Airbnb szállás adatai kerültek be, amelyek elsősorban a következőket tartalmazták:

- az Airbnb szállások száma, típusa (teljes lakás, privát szoba, közös szoba) és földrajzi elhelyezkedése,

- a szállások kapacitásadatai (férőhelyek, fürdószobák, szobák száma),

- a szállások ára,

- az üzemeltetők száma.

Az adatok lekérdezése, feldolgozása és adatbázisba rendezése után statisztikai elemzéseket végeztünk. Elsődlegesen a korrelációs együtthatókat vizsgáltuk meg, ahol 0,001-es szignifikancia szint mellett vettük figyelembe az eredményeket. Az ok-okozati összefüggéseket a nominális változók esetében Khí-négyzet próbával vizsgáltuk, míg a metrikus adatok esetében regresszió elemzést alkalmaztunk. Azonban hangsúlyozni szeretnénk, hogy a mélyebb összefüggések feltárása mindenképpen átfogóbb, kvalitatív elemzést kíván. Vizsgálatunk alátámasztásához felhasználtuk a Google Trends szolgáltatást, melyben az „Airbnb", illetve az "Airbnb Balaton" kulcsszavakra kerestünk rá a 2004 január és a 2019 február közötti időszakban. Az eredmények ábrázolására az OSM adatbázisból ingyenesen elérhetó alaptérképeket használtuk fel, melyeket a QGIS programban vizualizáltunk.

\section{Turizmus a balatoni régióban}

A Balaton és térsége a legrégebbi és leglátogatottabb üdülőhely Magyarországon mind a külföldi, mind a belföldi turistákat figyelembe véve (MADARÁSZ-PAPP 2013), továbbá Budapest után a második legjelentósebb turisztikai desztináció mind a vendégek, mind a vendégéjszakák számát tekintve (DOMONKOS et al. 2016, PUCZKÓRÁTZ 2000). A térség sikerességét a kedvező természetföldrajzi adottságok mellett az adja, hogy a kereskedelmi szállásadás mellett igen elterjedt jelenségnek számít a magánlakásokban történó vendégfogadás évszázadok óta ismert gyakorlata (GUTTENTAG et al. 2018) - ami Magyarországon
„Zimmer Frei"-ként került a köztudatba -, amely során magánszállásként a lakásállományt is bevonták a turisztikai kínálatba. Ennek következtében 2017 nyarára $^{6}$ a balatoni régió 180 településén 582 kereskedelmi szálláshely és több mint 18500 magánszállásadó kínált együttesen több mint 201 000 férőhelyet a térségbe látogató turistáknak. A féróhelyek többségét (53\%) (1. ábra) a magánszállások adják, míg a kínálat másik részének $(93000$ kereskedelmi féróhely) 37\%-a 45 kempinghez, a további 37\%-a 208 szállodához köthetô. A kapacitások térbeli eloszlása is mutat egyfajta koncentrációt, ugyanis magánszállásadással a 44 partmenti település mindegyikén foglalkoznak, és a 136 távolabbi településból is mindössze 36 településen nem volt ilyen tevékenység. Ezzel szemben, a kereskedelmi szálláshelyek a régióban csupán a települések közel egyharmadán (70) múködnek, fóként a partmenti településeken, de akad négy olyan partmenti település is, amely nem rendelkezik kereskedelmi szálláskínálattal.

$$
\begin{gathered}
\text { A szállásférőhelyek száma (db, \%) } \\
\text { szállástípusonként (2017) }
\end{gathered}
$$

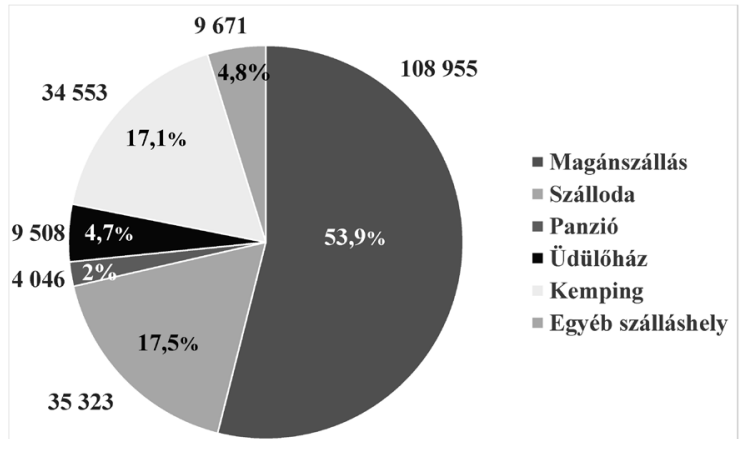

Forrás: saját szerkesztés a KSH adatai alapján

Vendégforgalom tekintetében a Balaton térsége a második leglátogatottabb turisztikai térség Magyarországon, és az elmúlt években folyamatos növekedést mutatott, így 2017-ben a KSH adatai szerint 2300000 turista több mint 7790000 vendégéjszakát töltött el a régió szállásain. A vendégforgalom eloszlása azonban meglehetósen egyenlótlen, ugyanis a vendégek közel 78\%-a kereskedelmi szálláshelyeken szállt meg, és a vendégéjszakák közel $74 \%$-a is ezen egységekhez köthetô. Mindemellett az is figyelemre méltó, hogy a térségbe érkező vendégek háromnegyede belföldi vendég, akik közel 80\%-ban kereskedelmi szállás-

\footnotetext{
${ }^{6} \mathrm{~A}$ tanulmány elkészítésének időpontjában nem voltak elérhetőek a magánszálláshelyekre vonatkozó 2018-as adatok, ezért használtuk a 2017-es értékeket.
} 
helyeket vesznek igénybe, míg a külföldi vendégek esetében ez az arány egy kicsivel alacsonyabb, $\mathrm{kb}$. $73 \%$-os. A turisták ilyen mértékú beáramlása jelentős hatással van a térség gazdaságára is, ami a KSH adatai szerint éves szinten több mint 66,6 milliárd forint árbevételt jelent a kereskedelmi szálláshelyeknek, ami az országos bevételek 14\%-át jelenti.

\section{Az Airbnb kínálata a balatoni régióban}

\section{1. ÁLTALÁNOS JELLEMZŐK}

A kutatás során gyúitött adatok azt mutatják, hogy 2018 júliusában 2417 szálláshelyen 1178 szállásadó 13420 férőhelyet kínált rövidtávú szállásszolgáltatás keretén belül az Airbnb platformján a balatoni régió településein. A szállásadó platformon hirdetett szállások kapacitás adatait a kereskedelmi szállások adataival összevetve megállapíthatjuk (1. táblázat), hogy az Airbnb-n hirdetett ingatlanok száma meghaladja a kereskedelmi szálláshelyek számát, azonban a kínált férôhelyek és szobák számát tekintve messze elmaradnak a kereskedelmi kínálattól, és a szállodák férőhelyeinek $45 \%$-át kínálják. Mindez természetesen nem meglepő, hiszen a kereskedelmi szálláshelyek átlagos férőhely/ egység mutatójának gazdaságossági okokból szükségszerúen magasabbnak kell lennie. Ugyanakkor az adatok rámutatnak a két szálláshely-kategória eltérő belsố szerkezetére.

1. táblázat

Az Airbnb és a kereskedelmi szálláskínálat jellemző́i a vizsgált mintaterületen (2018. július)

\begin{tabular}{|l|c|c|c|}
\hline \multicolumn{1}{|c|}{ Megnevezés } & $\begin{array}{l}\text { Szállásadó egy- } \\
\text { ségek száma }(\mathrm{db})\end{array}$ & $\begin{array}{c}\text { Férōhelyek } \\
\text { száma }(\mathrm{db})\end{array}$ & $\begin{array}{c}\text { Szobák } \\
\text { száma }(\mathrm{db})\end{array}$ \\
\hline Airbnb & 2417 & 13420 & 5609 \\
\hline $\begin{array}{l}\text { Kereskedelmi } \\
\text { szálláshelyek } \\
\text { összesen }\end{array}$ & 581 & 90677 & 19174 \\
\hline Ebból szálloda & 188 & 32192 & 12352 \\
\hline
\end{tabular}

Forrás: saját szerkesztés a KSH adatai és egyéni adatgyűjtés alapján

A régióban - a nemzetközi trendekhez is igazodva az Airbnb-n meghirdetett ingatlanok több mint 85\%a teljes lakás, kb. minden hetedik ingatlan privát szoba, míg a közös szobák aránya nem számottevő, még a fél százalékot sem éri el. A kínálat jellemzői azt is körvonalazzák, hogy a férőhelyek megoszlását tekintve még nagyobb koncentráció figyelhetó meg, ugyanis $89 \%$-a a teljes lakásokban összpontosul, ami átlagosan 5,6 féróhelyet és 4,4 ágyat jelent ebben a szállástípusban. A platform felületén az elérhetô szállásokat átlagosan 25000 forintért lehet lefoglalni (2. táblázat), azonban az árak egy igen széles spektrumot ölelnek fel, így foglalhatunk akár 2900 forintért is, de akad szállás több mint 400000 forintos áron is. A felmért Airbnb szállások átlagos árai és más középértékei között az eltérés 5000 10000 forint, míg a szórás 23000 forint körüli. Az adatokból a felsó szélsô (100 000 forint feletti) értékeket eltávolítva sem változnak a középértékek drasztikus mértékben. A módusz ugyanúgy 15000 forint, míg a medián körülbelül 300 forinttal, az átlag közel 2000 forinttal csökkent. Bár a ferdeség és a csúcsosság értéke jelentős mértékben változott, az adatok eloszlása tekintetében jelentôs változás nem történt (2. ábra), továbbra is pozitív, erósen bal oldali dôlésú és csúcsos. A szállások legtöbbje a 20000 forintos ár körülire pozicionált.

2. táblázat

Az Airbnb szálláskínálat átlagárai és statisztikai jellemzối a vizsgált mintaterületen (2018. július)

\begin{tabular}{|l|r|}
\hline \multicolumn{1}{|c|}{ Középérték } & \multicolumn{2}{c|}{ Ár (forint) } \\
\hline Átlag & 24605,29 \\
\hline Medián & 19365,00 \\
\hline Módusz & $15000,0^{a}$ \\
\hline \multicolumn{2}{|c|}{ Statisztikai jellemzök } \\
\hline Elemszám & 2417 \\
\hline Szórás & 23070,7184 \\
\hline Ferdeség & 6,274 \\
\hline Csúcsosság & \multicolumn{2}{c|}{} \\
\hline a több módusz közül a legkisebbet tüntettük fel \\
\hline
\end{tabular}

Forrás: saját szerkesztés egyéni adatgyüjtés alapján

\section{2. ábra}

Az Airbnb szállások árainak eloszlási görbéje a 100000 forint feletti kiugró adatok eltávolításával a vizsgált mintaterületen (2018. július)

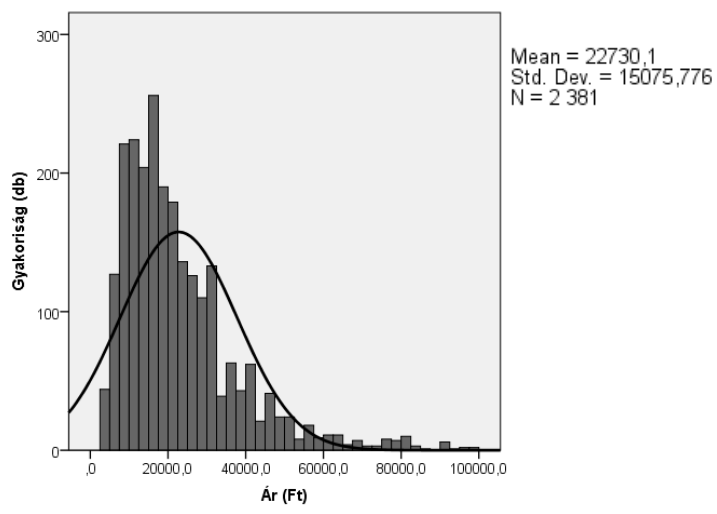

Forrás: saját szerkesztés egyéni adatgyűjtés alapján 
Lektorált tanulmányok

Az Airbnb felületén meghirdetett szállások kb. $75 \%$-a hat fó alatti a befogadóképességet tekintve, tehát a „klasszikus” magánszállás kategóriába sorolható (3. táblázat). A leggyakoribb szállástípus négy féróhellyel rendelkezik, ami a kínálat több mint 27\%-át adja, míg második helyen a hat férőhellyel rendelkezó szállások vannak (18\%), de a nyolc féróhelyes ingatlanok is $10 \%$ feletti részesedéssel bírnak. Mindemellett a kínálatban jelen van 239 olyan szállás is, ami tíznél több vendég elszál-

lásolására alkalmas. Ezek alapján arra következtethetünk, hogy a balatoni Airbnb kínálat elsősorban a több főre szállást kereső, az infokommunikációs technológiákat intenzíven használó fiatalokra, valamint az árérzékeny családosokra fókuszál. Ez a következtetés azonban további vizsgálatokat igényel. Ezt a kérdést azért is érdemes lenne vizsgálni, mert viszonylag kevés hazai kutatás fókuszált a P2P szállásadás keresleti oldalára.

Az Airbnb kínálat a Balaton turisztikai régióban a féróhelyek és a szállásadók által üzemeltetett ingatlanok száma alapján (2018. július)

\begin{tabular}{|c|c|c|c|c|c|c|c|}
\hline \multicolumn{4}{|c|}{ A féróhelyek száma szerint } & \multicolumn{4}{|c|}{ Az üzemeltett ingatlanok száma szerint } \\
\hline Féröhely & $\begin{array}{c}\text { Szálláshely } \\
(d b)\end{array}$ & $\begin{array}{c}\text { Megoszlás } \\
(\%)\end{array}$ & $\begin{array}{l}\text { Átlagos } \\
\text { szállásár } \\
\text { (forint/ } \\
\text { éjszaka) }\end{array}$ & $\begin{array}{c}\text { Üzemeltetett } \\
\text { ingatlanok } \\
\text { száma }(d b)\end{array}$ & $\begin{array}{l}\text { Szállásadók } \\
\text { száma }(d b)\end{array}$ & $\begin{array}{c}\text { Szállásadók } \\
\text { aránya } \\
(\%)\end{array}$ & $\begin{array}{c}\text { Átlagos } \\
\text { szállásár } \\
\text { (forint/ } \\
\text { éjszaka) }\end{array}$ \\
\hline 1 & 7 & 0,29 & 9461 & 1 & 893 & 75,81 & 28274 \\
\hline 2 & 319 & 13,20 & 14071 & 2 & 149 & 12,65 & 25268 \\
\hline 3 & 127 & 5,25 & 15310 & 3 & 52 & 4,41 & 21478 \\
\hline 4 & 670 & 27,72 & 19615 & 4 & 37 & 3,14 & 24143 \\
\hline 5 & 237 & 9,81 & 20786 & 5 & 14 & 1,19 & 24311 \\
\hline 6 & 447 & 18,49 & 26270 & 6 & 10 & 0,85 & 35172 \\
\hline 7 & 89 & 3,68 & 27113 & 7 & 5 & 0,42 & 22561 \\
\hline 8 & 245 & 10,14 & 32148 & 8 & 5 & 0,42 & 32037 \\
\hline 9 & 37 & 1,53 & 31635 & 9 & 2 & 0,17 & 20484 \\
\hline 10 & 95 & 3,93 & 45150 & $10+$ & 11 & 0,93 & 20147 \\
\hline 11 & 12 & 0,50 & 40553 & & & & \\
\hline 12 & 46 & 1,90 & 42917 & & & & \\
\hline 13 & 12 & 0,50 & 33712 & & & & \\
\hline 14 & 19 & 0,79 & 61505 & & & & \\
\hline 15 & 5 & 0,21 & 106126 & & & & \\
\hline 16 & 50 & 2,07 & 57025 & & & & \\
\hline
\end{tabular}

Forrás: saját szerkesztés egyéni adatgyüjtés alapján 
Kezdetben az Airbnb koncepciója azon alapult, hogy a magánszemélyek megosztják felesleges ingatlankapacitásaikat olyan emberekkel, akiknek szállásra volt szükségük. Ezzel extra bevételekhez jutnak, amelyek segíthetnek nekik a lakbér, vagy a lakáshitel törlesztô részleteinek kifizetésében. Ez a trend késóbb átalakult, és a nagyvárosokban a magáncélú hasznosítás mellett az ingatlanok üzleti célú hasznosítása egyre inkább elótérbe került az Airbnb felületén (JANCSIK et al. 2018). A nemzetközi szakirodalomban nincs egységes konszenzus arról, hány üzemeltetett ingatlantól tekinthetjük „professzionális" vagy „üzleti” felhasználónak a szállásadókat (KE 2017), ezért az egynél több lakást kínáló hosztok már üzleti szolgáltatóknak tekinthetők (JANCSIK et al. 2018). A balatoni régióban a szállásadók kb. 75\%-a csupán egy ingatlant hirdet az Airbnb platformján, azonban a professzionális múködés fokozottan van jelen (3. táblázat), hiszen a lakások több mint 63\%-a kettő vagy annál több üzemeltetó birtokában van, ami jelentôsen felülmúlja a budapesti arányokat, ahol ez az érték valamivel több mint 50\% felett mozog (JANCSIK et al. 2018). Mindemellett figyelemre méltó az is, hogy a hat és annál több ingatlant menedzseló üzemeltetők kevesebb mint 2\%-át teszik ki az üzemeltetőknek, mégis az ô igazgatásuk alatt van a kínált ingatlanok több mint 32\%-a. E folyamatok azt feltételezik továbbá, hogy a balatoni régióban igen erôs a befektető́k és a professzionális üzemeltetók jelenléte, amit alátámaszt, hogy a térségben található olyan szállásadó, aki 200-nál is több ingatlant üzemeltet, így vélhetóen a bevételek egy jelentős része is egy szúk kör kezében összpontosul.

\subsection{TERÜLETI JELLEMZÖK}

Az adatok elemzéséból megállapítható, hogy az Airbnb szállások megoszlása a Balaton térségében meglehetósen egyenlótlen (3. ábra). A felmért adatok alapján az körvonalazódik, hogy a déli oldalon nagyobb számban fordul elő Airbnb szálláshely, valamint egy jelentôs súrúsödési pont mutatkozik Keszthely és Hévíz környékén. Továbbá az is jól látszik, hogy az északi oldalon sokkal diffúzabb a jelenség, vagyis sokkal több településen található meg, mint turisztikai jelenség, de számában alacsonyabb, mint a déli oldalon.

A kutatásban a balatoni régió Airbnb kínálatának általános jellemzői mellett megvizsgáltuk, hogy egy turisztikai régióban is érvényesülnek-e a nemzetközi trendek a P2P szállásadás tekintetében, vagyis hogy az Airbnb mennyire tekinthetó urbánus jelenségnek, milyen mértékben kötődik nagyobb népességszámhoz. Feltevésünk az volt, hogy minél nagyobb, népesebb egy település, an- nál nagyobb valószínúséggel és számban jelennek meg Airbnb szálláshelyek az adott településen. Bár logikusnak túnik, hogy a nagyobb népességszám több lakást, ezáltal több kiadható féróhelyet jelent, de az Airbnb esetében nem biztos, hogy ez érvényesül. Nemzetközi összehasonlításban a magas népességszám nem feltétlenül eredményez magas Airbnb számot. Az ezer főre jutó Airbnb szálláshelyek budapesti értéke 6,05, Bukaresté 1,96, Pozsonyé 3,04, Bécsé 4,77, míg Prágáé 10,03. Magyarországi viszonylatban is nagyok a különbségek, például Szegeden 1,26, Debrecenben 0,56, Miskolcon 0,32, Siófokon 11,81 ez az érték. A népességszám és az Airbnb szállások száma közötti kapcsolat vizsgálatára a népességszám és az Airbnb-n hirdetett szállások száma közötti korrelációs együtthatót vizsgáltuk meg, mely 0,001-es szignifikancia szint mellett erős, 0,709-es együtt mozgást mutatott. Mindemellett megvizsgáltuk az épületállomány és az Airbnb szállások együtt mozgását is. Ebben az esetben még erősebb, 0,764es korrelációs értéket kaptunk, ami arra utalhat, hogy a népességszám és az épületállomány növekedésével, ha nem is egyenesen arányosan, de növekszik az Airbnb szálláshelyek száma a BKÜ területén. Az Airbnb tehát a diffúzió tekintetében egy turisztikai régióban is inkább hierarchikus jelleget mutat. Ez azonban kiegészül azzal, hogy nemcsak a hagyományos város-falu viszony vagy a népességszám adja a hierarchia alapját, hanem a turisztikai szolgáltatások sokszínúsége is.

\section{Az Airbnb szálláshelyek eloszlása} a Balaton térségében

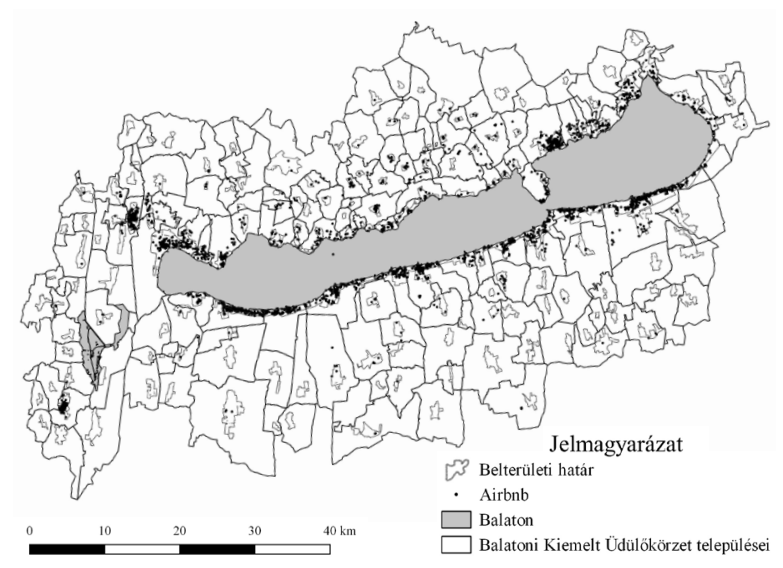

Forrás: saját szerkesztés egyéni adatgyüjtés alapján

Ha az Airbnb elterjedésének idó- és térbeliségét kívánjuk felvázolni, akkor szükséges vizsgálni, hogy milyen régóta és hol adják ki az ingatlanokat. Azonban az Airbnb-n a szállások adatlapján 
Lektorált tanulmányok

a szállás üzemeltetőjének regisztrációs dátuma látható, nem pedig a lakás megjelenéséé. Szerencsére a hosztok több mint háromnegyede (75,81\%-a) egyetlen egy ingatlant ad ki az Airbnb felületén, vagyis valószínúsíthetó, hogy a hoszt regisztrációjának az ideje egybeesik a kiadott ingatlan regisztrációjának az idejével. Erre egyértelmú bizonyíték azonban nincs, hiszen ismeretlen, hogy az üzemeltető a jelenleg üzemeltetett ingatlant adta-e ki a regisztráció időpontjában, vagy korábban már regisztrált egy másik ingatlant, amit valamilyen okból kifolyólag törölt, és új hirdetéssel jelent meg a piacon. A legrégebbi regisztrációk idópontjai és a felmérés idejében megtalálható kiadó szálláshelyek száma által körvonalazódó településcsoport a hagyományos balatoni turizmus kiemelkedố településeit takarja, mint például Siófok, Balatonfüred, Hévíz, Balatonboglár, Fonyód (4. ábra).

Az Airbnb szálláshelyeket kiadó regisztrált felhasználók számának (db) alakulása a Balaton térség kiemelt településein

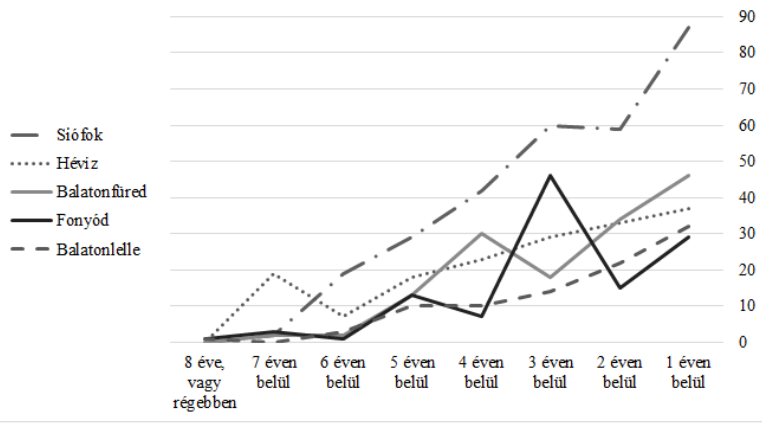

Forrás: saját szerkesztés egyéni adatgyüjtés alapján

Bár az eredményekkel kapcsolatosan több bizonytalanság is fennáll, mégis jó közelítést adhatnak a téma további vizsgálatához, illetve felhívják a figyelmet arra, hogy longitudinális vizsgálatok szükségesek a téma további, alaposabb körüljárásához.

Bár a jelenleg felmért legkorábbi, 2011. februári, regisztráció előtti Airbnb kiadások léte vagy nem léte nem bizonyítható, a P2P szálláshelyek ez időpont elótti ismertségét jellemezheti az internetes keresések alakulása. Ezért a Google Trends felhasználásával megvizsgáltuk, hogy milyen gyakoriságban keresték a Google keresóben az Airbnb-t általánosságban, illetve a Balaton környékén 2009 szeptember és 2019 február között. Eredményként összegezhető, hogy a legtöbb keresés 2018 júniusában volt mind az „Airbnb”, mind az „Airbnb Balaton" kulcsszavakra, a trend pedig növekvő (5. ábra).

\section{Az "Airbnb" és az „Airbnb Balaton" kulcssza- vak keresettsége a 2009. szeptember -} 2019. január időszakban

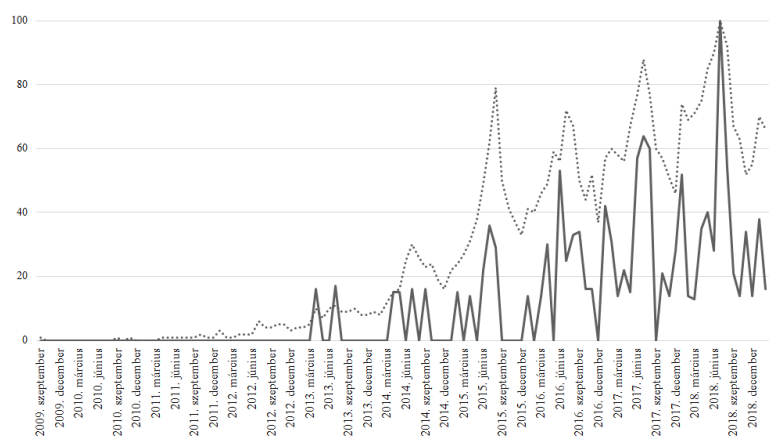

Forrás: saját szerkesztés Google Trends adatok alapján

A Balaton esetében a keresések 100\%-a Budapestról érkezett a vizsgált időszakban. Ráadásul 2009 szeptembere elótt egyetlen egy általunk keresett kulcsszóra sem történt keresés, mivel maga az Airbnb 2008-ban jött létre, és terjedése még nem érhetett el az általunk vizsgált térségbe. Így bár bizonyítani nem lehet, de a keresési elózmények és a 2011-ben elérhetô alacsony számú (összesen 4 db) szállás alapján valószínúsíthetô, hogy a vizsgált időszakban a kiadott szálláshelyek számában súlyponteltolódás nem tapasztalható.

A jelenleg elérhetó felhasználói adatok alapján az az állításunk, mely szerint az Airbnb a településhierarchia magasabb szintjén jelenik meg, a városokban, illetve a turisztikailag kiemelkedó településeken, igazolódni látszik, de ahogy más esetekben, itt is szükség lenne további adatgyújtésre és elemzésre, hogy megalapozottabb következtetéseket vonhassunk le.

A népesség és az épületállomány, vagyis a település fizikai és társadalmi "kiterjedése" azonban nem az egyetlen faktor, mely befolyásolhatja a szálláshelyek, azon belül is a P2P elven múködőek, számát és földrajzi eloszlását. Több szakirodalom is értekezik a távolság differenciáló hatásáról (BAKUCZ et al. 2015). Ezért a kutatásban megvizsgáltuk a BKÜ területén található Airbnb-k földrajzi eloszlását, illetve megkíséreltünk magyarázatot adni a felmért P2P szálláshelyek sûrúsödésének okaira. Több kutató is kitér az infrastrukturális ellátottság, ezen belül is a megközelíthetőség, turizmusban betöltött szerepére (BAKUCZ et al. 2015, MICHALKÓ 2007, TÓTH-DÁVID 2009). Megállapítják, hogy azok a turisztikai desztinációk, amelyek könnyebben megközelíthetőek, népszerúbbek és magasabb vendégéjszaka számokat produkálnak a hasonló adottságokkal rendelkező, 
de nehezebben megközelíthető versenytársaiknál. Mivel a közösségi gazdaság és az Airbnb urbánus jelenségnek tekinthetők, terjedésük a fentebb említett módon hierarchikus és egyben expanziós jellegú. Ez azt feltételezi, hogy azokon a településeken, amelyek esetlegesen egy nagyobb, a településhierarchiában magasabb pozíciót elfoglaló településhez - például megyeszékhely, regionális központ vagy esetleg fóváros - földrajzilag vagy időtávolság szempontjából közelebb helyezkednek el, nagyobb számban találunk Airbnb szállásokat. Ennek érdekében megvizsgáltuk, hogy egyrészt, a Budapesttől mért időtávolság (6. ábra) mennyiben magyarázza a felmérés időpontjában elérhető Airbnb-k számát, másrészt, hogy az autópálya-lehajtóktól való távolság befolyásolja-e megjelenésüket. Ehhez regresszió analízist végeztünk el. Előbbi vizsgálat esetében $\mathrm{R}=0,016$-os értéket kaptunk, míg a második esetben $\mathrm{R}=0,032$-es értéket mértünk, amelyek alapján megállapítható, hogy sem Budapesthez, sem pedig az autópálya lehajtókhoz való közelség/távolság nem befolyásolja és nem is magyarázza a szálláshelyek földrajzi eloszlását.

6. ábra

A Balaton parti települések Budapesttől mért idótávolsága

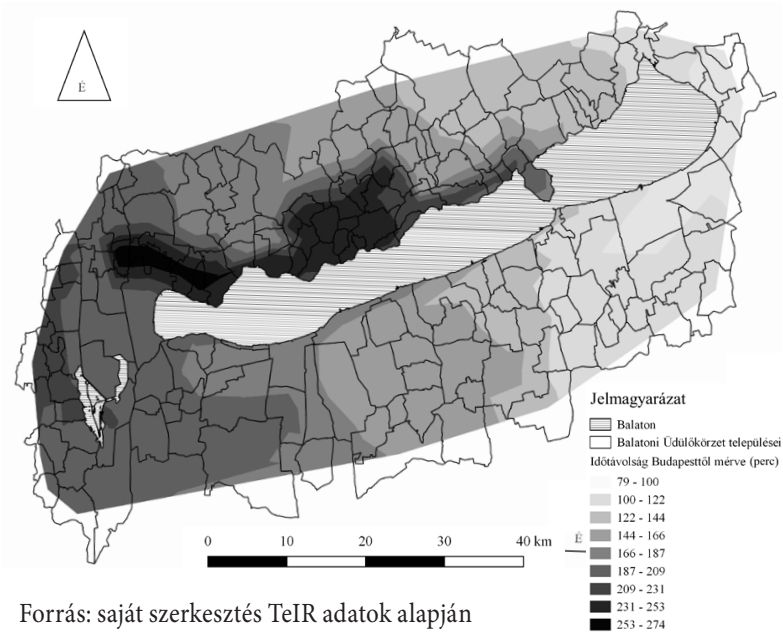

A Budapesttől való távolság mellett a szállások parttól való földrajzi távolságának differenciáló hatását is vizsgáltuk (4. táblázat). A balatoni térség településeit két kategóriára osztottuk:

- a Balatontól távolabbi (nem partmenti) településekre,

- és Balaton-parti településekre.

Megvizsgáltuk, hogy kimutatható-e szignifikáns különbség a meghirdetett Airbnb-k száma és a „Balaton-partiság” között. A t-próba eredménye alapján megállapítható, hogy a Balaton-parton szignifikánsan több Airbnb található, mint a Balatontól távolabb. A kapcsolat igazolására kereszttábla elemzést is végeztünk, amelyhez a két nominális változót az Airbnb szálláshely megléte (igen-nem), illetve a Balatonhoz való közelség (parti, távolabbi) adta. Az elemzés során a Khí-négyzet próba 1-es szabadsági fok mellett 47,632-es értéket vett fel, mely szerint a nullhipotézisünk, azaz, hogy a Balatonhoz való viszonynak (közel-távol) nincs hatása az Airbnb megjelenésére, megdőlt. Az adatok szorosságára vonatkozó Cramer-V érték 0,514, vagyis az adatok közepesen erősen kapcsolódnak össze.

Annak érdekében, hogy ne csak nominális, hanem metrikus adatokkal is teszteljük a Balaton-part, mint turisztikai attrakció Airbnb szálláshelyekre gyakorolt hatását, további elemzést végeztünk a Balaton-parttól mért tényleges, méterben mért távolság és az Airbnb-k száma között. A távolság és az Airbnb-k száma közötti korrelációs együttható értéke -0,318 volt - 0,01-es szignifikancia szinten -, vagyis a parttól való távolság gyengén és ellentétesen mozog a kiadott szálláshelyek számával. Így a korábbi észrevételekkel együtt megállapíthatjuk, hogy a BKÜ településein az Airbnb szállások megjelenését egy turisztikai attrakció, vagyis a Balaton partja jobban befolyásolhatja, mint az elérhetóség. Mindez természetesen az üdülőturizmus jellegzetességeiból is következik.

A Balaton, mint komplex turisztikai termék nem csupán strandjai miatt népszerú, hanem borvidékek tekintetében is az ország legszíne-

Az Airbnb-k számának megoszlása a partközeli és a nem partközeli települések között

4. táblázat

\begin{tabular}{|c|c|c|c|c|c|c|c|c|}
\hline \multirow{2}{*}{\multicolumn{2}{|c|}{ Megnevezés }} & \multirow{2}{*}{$\begin{array}{c}\text { Elemszám } \\
(d b)\end{array}$} & \multirow{2}{*}{ Átlag } & \multirow{2}{*}{ F-érték } & \multirow{2}{*}{ t-érték } & \multicolumn{2}{|c|}{ Airbnb } & \multirow{2}{*}{ Khí-négyzet } \\
\hline & & & & & & van & nincs & \\
\hline \multirow{2}{*}{$\begin{array}{c}\text { Airbnb-k } \\
\text { száma }\end{array}$} & $\begin{array}{c}\text { Balaton } \\
\text { partközeli }\end{array}$ & 52 & 41,23 & \multirow{2}{*}{89,213} & \multirow{2}{*}{8,217} & 0 & 52 & \multirow{2}{*}{47,632} \\
\hline & $\begin{array}{l}\text { Balaton } \\
\text { további }\end{array}$ & 128 & 2,13 & & & 71 & 57 & \\
\hline
\end{tabular}

Forrás: saját szerkesztés 
Lektorált tanulmányok

sebb választékát adja, ugyanis a balatoni régió területén összesen öt darab történelmi borvidék található. A vizsgálatunkban összesen 109 településen mértünk Airbnb szálláshelyet, amelyek közül 77 település borvidékhez tartozott, míg 32 nem (7. ábra). Ezek alapján, a kutatás során arra is kerestük a választ, hogy a borvidékeken nagyobb valószínúséggel jelennek-e meg az Airbnb típusú szálláshelyek. A Khí-négyzet próba eredménye alapján (Khí=27,319; df=1; szig=0,001) a borvidékhez tartozás és az Airbnb megjelenése között kimutatható egyfajta kapcsolat, ugyanis a borvidékeken nagyobb eséllyel található Airbnb szálláshely, mint azokon a településeken, melyek nem tartoznak egyetlen borvidékhez sem. A meghirdetett Airbnb szállások számát azonban nem befolyásolja érdemben a borvidékhez való tartozás, vagyis a borvidék önmagában nem feltétlenül okozója a magasabb Airbnb számnak.

\section{A Balaton körüli borvidékek települései és a településeken található Airbnb szállások száma}

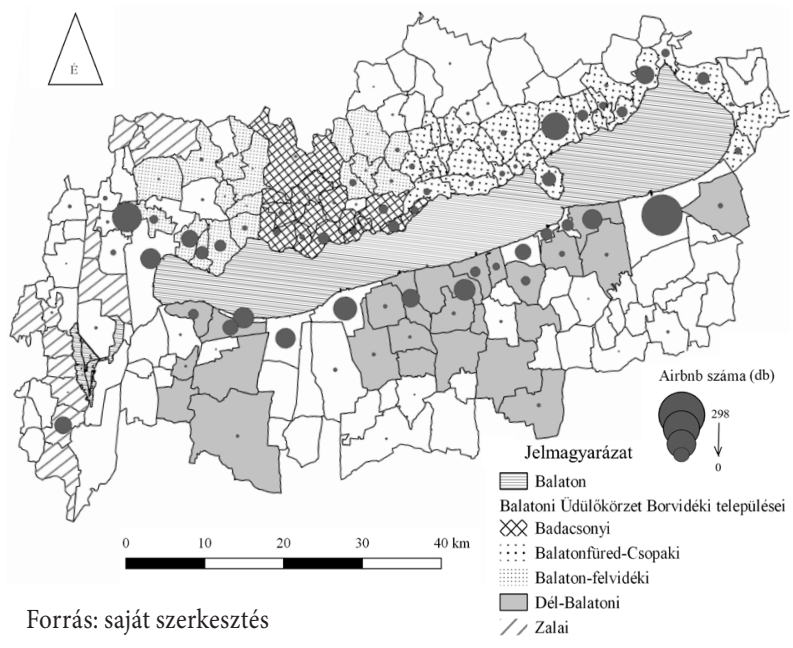

A borvidékek esetében megvizsgáltuk továbbá az Airbnb szállások átlagos árait is (5. táblázat), azt feltételezve, hogy azok között nincs szignifikáns különbség. Feltételeztük tehát, hogy a borvidékhez való tartozás nem differenciál az átlagárban. Az eredmények alapján az árban nem a borvidékhez tartozás az, ami a legmeghatározóbb, hanem feltehetőleg a borvidék imázsa, annak népszerúsége. Így lehetséges az, hogy a napjainkban egyre népszerúbbé váló Balatonfüred térsége értékesebb, mint a bor tekintetében kevésbé elismert Dél-Balaton, vagy a köztudatba kevésbé beágyazódott Zalai borvidék. Mivel egyértelmú összefüggést nem találtunk a borvidékhez tartozás és az Airbnb-k száma között, így az árakra gyakorolt hatás is feltételes.
A Balaton körüli borvidékeken található Airbnb szállások átlagára (2018. július)

\begin{tabular}{|c|c|}
\hline Borvidék & Átlagár $($ Ft $)$ \\
\hline Badacsonyi & 23552 \\
\hline Balatonfüred-Csopaki & 27723 \\
\hline Balaton-felvidéki & 25220 \\
\hline Dél-Balatoni & 20417 \\
\hline Zalai & 15454 \\
\hline nem borvidék & 21964 \\
\hline
\end{tabular}

Forrás: saját szerkesztés

\section{5. Összefoglalás}

Kutatásunkban a rövidtávú szállásszolgáltatás (Airbnb) helyzetét mutatjuk be a Balatoni Turisztikai Régióban, és elemezzük, hogy a települések népességszáma, a földrajzi távolság, valamint a borvidékek milyen hatással vannak az Airbnb kínálatra. Eredményeink azt mutatják, hogy habár az Airbnb döntően nagyvárosi jelenség, valamint a jelentős turisztikai vonzerővel rendelkezô városokban terjedt el (ADAMIAK 2018, GUTIÉRREZ et al. 2017), a Balatoni Turisztikai Régióban is jelen van. Vizsgálatunk megerósítette, hogy az Airbnb elsősorban urbánus jelenségnek tekinthető, ugyanakkor nem igazolta a településhierarchiának az Airbnb szállások számára gyakorolt pozitív hatását.

Az eredményeket összegezve megállapíthatjuk, hogy a balatoni Airbnb kínálat illeszkedik a hazai (DUDÁS et al. 2018) és budapesti (JANCSIK et al. 2018) trendekhez, ugyanakkor nemzetközi kontextusba helyezve megállapítható, hogy a balatoni térség Airbnb kínálatában sokkal magasabb a teljes lakások részaránya, mint a globális Airbnb piac $(68,5 \%)$ (KE 2017), vagy akár a nyugat-európai országok (ABDAR-YEN 2017) viszonylatában. A kutatás rávilágított továbbá arra, hogy az Airbnb felületén kiadott szállások több mint 75\%-a egy üzemeltető gondozásában van. Ugyanakkor a professzionális lakáskiadás fokozottan van jelen, hiszen a hat vagy annál több ingatlant menedzseló szállásadók részaránya $2 \%$ alatti, mégis ők kezelik a kínált szállások több mint 32\%-t. Ezek a számok azt is sugallhatják továbbá, hogy a balatoni régióban az Airbnb nem tekinthetô pusztán a felesleges ingatlankapacitások magánjellegú megosztására és hasznosítására használt platformnak - amely célra 2008-ban megalapították -, hanem bizonyos esetekben sokkal inkább egy üzleti motiváció által vezérelt lakáskiadó platform. 
A kutatás további iránya lehetne az adatgyújtés jövőbeni szisztematikus megismétlése az Airbnb terjedésének figyelemmel kísérése érdekében. Emellett érdemes lenne mélyebben megvizsgálni az Airbnb kereskedelmi szálláshelyekre gyakorolt hatását, illetve az adott települések ingatlanpiacára gyakorolt hatásait a Balatoni Turisztikai Régióban, és azt összehasonlítani a nemzetközi trendekkel.

\section{Köszönetnyilvánítás}

A tanulmányban ismertetett kutatás a 128015 számú „A magyarországi közösségi szállásadás földrajzi vizsgálata" projekt részeként a Nemzeti Kutatási Fejlesztési és Innovációs Alap támogatásával valósult meg.

\section{Felhasznált irodalom}

ABDAR, M. - YEN, N. Y. (2017): Understanding regional characteristics through crowd preference and confidence mining in P2P accommodation rental service. Library Hi Tech. 35(4). pp. 521-541.

ADAMIAK, C. (2018): Mapping Airbnb supply in European cities. Annals of Tourism Research. 71(C). pp. 67-71.

BAKUCZ M. - BOZÓTI A. - KOVÁCS Á. PÓTÓ ZS. (2015): A közúti elérhetőség szerepe a hazai fürdőtelepülések turisztikai versenyképességében. Területi Statisztika. 55(1). pp. 60-75.

BÁLINT D. - MAGYAR-PAPP J. (2016): Megosztáson alapuló gazdaság a turizmus szektorban: Esettanulmány Pécsról. In: Pajtókné Tari I. - Tóth A. (szerk.): Magyar Földrajzi Napok 2016. Konferenciakötet. Eszterházy Károly Egyetem-Magyar Földrajzi Társaság-Agria Geografia Alapítvány, Eger. pp. 676-686.

BÁLINT, D. - TRÓCSÁNYI, A. (2016): New ways of mobility: the birth of ridesharing. A case study from Hungary. Hungarian Geographical Bulletin. 65(4). pp. 391-405.

BLAL, I. - SINGAL, M. - TEMPLIN, J. (2018): Airbnb's effect on hotel sales growth. International Journal of Hospitality Management. 73. pp. 85-92.

BOROS, L. - DUDÁS, G. - KOVALCSIK, T. - PAPP, S. - VIDA, GY. (2018): Airbnb in Budapest: Analysing spatial patterns and room rates of hotels and peer-to-peer accommodations. GeoJournal of Tourism and Geosites. 21(1). pp. 26-38.

CHENG, M. (2016): Sharing economy: A review and agenda for future research. International Journal of Hospitality Management. 57. pp. 60-70.
DOMONKOS Á. - SINKOVICS K. - RETZ T. (2016): Turizmusgazdaság a Balaton idegenforgalmi régióban. Területi Statisztika. 56(3). pp. 346-368.

DUDÁS G. - BOROS L. (2019): A közösségi gazdaság (sharing economy) definiálásának dilemmái. Tér és Társadalom. 33(1). pp. 107-130.

DUDÁS G. - BOROS L. - PÁL V. (2016): Közösségi szállásadás Budapesten - Az Airbnb térnyerése. Településföldrajzi Tanulmányok. 5(3-4). pp. 66-83.

DUDÁS, G. - BOROS, L. - KOVALCSIK, T. KOVALCSIK, B. (2017a): The visualisation of the spatiality of Airbnb in Budapest using 3-band raster representation. Geographica Technica. 12(1). pp. 23-30.

DUDÁS G. - KOVALCSIK T. - BOROS L. KOVALCSIK B. - VIDA GY. (2018): Az Airbnb szálláskínálatának jellemzői a megyei jogú városokban. Területi Statisztika. 58(5). pp. 462-488.

DUDÁS, G. - VIDA, GY. - KOVALCSIK, T. BOROS, L. (2017b): A socio-economic analysis of Airbnb in New York City. Regional Statistics. 7(1). pp 135-151.

FANG, B. - YE, Q. - LAW, R. (2016): Effect of Sharing Economy on Tourism Industry Employment. Annals of Tourism Research. 57. pp. 264-267.

FORNO, F. - GARIBALDI, R. (2015): Sharing economy in travel and Tourism: The case of home-swapping in Italy. Journal of Quality Assurance in Hospitality and Tourism. 16(2). pp. 202-220.

GININDZA, S. - TICHAAWA, T. M. (2017): The impact of sharing accommodation on the hotel occupancy rate in the kingdom of Swaziland. Current Issues in Tourism. pp. 1-17.

GUTIÉRREZ, J. - GARCÍA-PALOMARES, J. C. ROMANILLOS, G. - SALAS-OLMEDO, M. H. (2017): The eruption of Airbnb in tourist cities: Comparing spatial patterns of hotels and peer-to-peer accommodation in Barcelona. Tourism Management. 62. pp. 278-291.

GUTTENTAG, D. (2015): Airbnb: disruptive innovation and the rise of an informal tourism accommodation sector. Current Issues in Tourism. 18(12). pp. 1192-1217.

GUTTENTAG, D. - SMITH, S. - POTWARKA, L. - HAVITZ, M. (2018): Why Tourist Choose Airbnb: A Motivation-Based Segmentation Study. Journal of Travel Research. 57(3). pp. 342359.

GYÓDI, K. (2017): Airbnb and the hotel industry in Warsaw: An example of the sharing economy? Central European Economic Journal. 2(49). pp. 23-34. 
Lektorált tanulmányok

HAMARI, J. - SJÖKLINT, M. - UKKONEN, A. (2016): The sharing economy: Why people participate in collaborative consumption. Journal of the Association for Information and Science and Technology. 9(67). pp. 2047-2059.

JANCSIK A. - MICHALKÓ G. - CSERNYIK M. (2018): Megosztás megosztottság nélkül - az Airbnb és a budapesti szálláshelypiac átalakulása. Közgazdasági Szemle. 65(3). pp. 259-286.

KARAKASNÉ MORVAY, K. (2017): Satisfaction and characteristics of Airbnb demand in Budapest. Zbornik Radova Departmana Za Geografiju Turizam I Hotelijertsvo. 42(2). pp. 76-88.

KE, Q. (2017): Sharing Means Renting?: An Entiremarketplace Analysis of Airbnb. Proceedings of the 2017 ACM on Web Science Conference. pp. 131-139.

MADARÁSZ, E. - PAPP, ZS. (2013): Delimiting the „Balaton Riviera" tourist destination by using network analysis. Hungarian Geographical Bulletin. 62(3). pp. 289-312.

MICHALKÓ G. (2007): Magyarország modern turizmusföldrajza. Dialóg Campus Kiadó, Budapest.

OLMEDILLA, M. - MARTÍNEZ-TORRES, M. R. - TORAL, S. L. (2016): Harvesting Big Data in social science: A methodological approach for collecting online user-generated content. Computer Standards \& Interfaces. 46. pp. 79-87.

PÁSZTOR M. - UGRÓSDY GY. - VILLÁNYI J. (2017): A fogyasztói árstatisztika gyújtésének módjai. In: Lehota J. (szerk.): Eletem a felsóoktatásban: Dr. Molnár József 70 éves. Szent István Egyetem Kiadó, Gödöllő. pp. 37-43.

PUCZKÓ, L. - RÁTZ, T. (2000): Tourist and Resident Perceptions of the Physical Impacts of Tourism at Lake Balaton, Hungary: Issues for Sustainable Tourism Management. Journal of Sustainable Tourism. 8(6). pp. 458-478.

SALVIONI, D. M. (2016): Hotel Chains and the Sharing Economy in Global Tourism. Symphonia, Emerging issues in Management. 1. pp. 31-44.

SAHLMAN, E-M. (2018): Sharing economy as disruptive innovation: consumer viewpoint. Bachelor's Thesis. Aalto University School of Business.

SCHNEIDER, H. (2017): Creative destruction and the sharing economy. Uber as a disruptive innovation. Edwars Elgar Publishing, Cheltenham, UK.
SMITH, M. - EGEDY, T. - CSIZMADY, A. JANCSIK, A. - OLT, G. - MICHALKÓ, G. (2018): Non-planning and tourism consumption in Budapest's inner city. Tourism Geographies. 20. pp. 524-548.

SÜLI D. - MARTYIN-CSAMANGÓ Z. (2017): A közösségi média szerepe a fesztiválturizmusban - a Szegedi Ifjúsági Napok és a Green Future példáján. Turizmus Bulletin. 17(3-4). pp. 24-32.

TEUBNER, T. - HAWLITSCHEK, F. - DANN, D. (2017): Price determinats on Airbnb: How reputation pays off in the sharing economy. Journal of Self-Governance and Management Economics. 5(4). pp. 53-80.

TÓTH G. - DÁVID L. (2009): Az elérhetôség és az idegenforgalom kapcsolata. Tér és Társadalom. 23(3). pp. 45-62.

ZERVAS, G. - PROSERPIO, D. - BYERS, J. W. (2017): The rise of the Sharing economy: Estimating the impact of Airbnb on the hotel industry. Journal of Marketing Research. 54. pp. 687-705.

\section{Internetes források}

AIRBNB (2018): Fast facts. https://press.atairbnb. com/fast-facts/, Letöltve: 2018. június 6.

FORBES (2018): As a rare profitable unicorn, Airbnb appears to be worth at least $\$ 38$ billion. https://www.forbes.com/sites/greatspeculations/2018/05/11/as-a-rare-profitable-unicornairbnb-appears-to-be-worth-at-least-38-billion/, Letöltve: 2018. október 10.

RANCHORDÁS, S. - ZUREK, K. - GEDEON, ZS. (2016): Home-Sharing in the Digital Economy: The cases of Brussels, Stockholm and Budapest. Impulse Paper prepared for the European Commission. https://ec.europa.eu/ docsroom/documents/16950/attachments/1/ translations/en/renditions/native, Letöltve: 2018. június 10.

STATISTA (2018): Leading hotel brands based on brand value worldwide in 2017 (in billion U.S. dollars). https://www.statista.com/statistics/732907/most-valuable-hotel-brands-worldwide/, Letöltve: 2018. október 10. 